\title{
Property Rights and Agricultural Development. The Land Issue in Equatorial Guinea
}

\author{
By Bernd Holznagel, Cord Jakobeit 1
}

\section{Introduction}

Contrary to a popular belief, land rights in Africa are not organized in one single system i.e. domination of forms of communal ownership - but have evolved in a variety of systems in response to changing political, social, and economic conditions. 2

Govemmental intervention, ranging from the distribution of land to white settlers in colonial days to the land legislation of the postcolonial state, has not often been conducive to economic development. Nevertheless, the theoretical evidence is clear: efficiency and economic development ultimately require formal recognition of individual land rights. Growth in population density is rapidly putting an end to the abundance of land and to primitive farming methods (long bush-fallow periods). To provide strong incentives to improve the land, and to adopt modem techniques for restoring fertility to it, a permanent and enforceable land rights system must evolve. Since technological advances are relatively capital-intensive, the using of land as collateral for credit requires that a reliable system of individual land documentation and registration will be developed.

Africa is in the midst of such a process, with the individualization of ownership increasing. However, due to the varying colonial heritages and the differing natural settings - eg. Kenya with a relatively little arable land compared to fertile Côte d'Ivoire as an extreme example - we find that this process takes shape in different forms in different countries. This paper takes the empirical case of a small state in western equatorial Africa to illustrate two points: a) the role land plays in the agricultural development of a country and b) the extent and nature of governmental intervention on the land issue.

1 The authors wish to thank Robert Klitgaard - administrator of the Economic Rehabilitation Project of the World Bank in Equatorial Guinea, formerly Associate Professor of Public Policy, Harvard University, - for valuable support and hospitality in Malabo, Equatorial Guinea, during our research stays.

2 For a recent discussion of these questions in a continent-wide context see G. Feder/R. Noronha, Land Right Systems and Agricultural Development in Sub-Saharan Africa, The World Bank Research Observer, Vol. I, No. 2, 1987, pp. 143-169. 
After a short introduction to Equatorial Guinea ${ }^{3}$, we proceed to highlight the crucial importance of the land issue for the country's economic rehabilitation. We discuss different approaches which have been attempted to reanimate the country's production of cocoa, the number 1 export of this tiny nation. We comment on the likelihood of economic rehabilitation under the existing land right system. In the final summary, we return to the relevance of our results for Africa as a whole and the role that the land issue plays in the process of developing Africa.

\section{Recent Development in Equatorial Guinea}

After gaining independence from Spain in 1968, Equatorial Guinea went through a nightmare that is comparable only to what had happended in Cambodia under Pol Pot, or in Uganda under Idi Amin: with one difference - the decade-long dictatorship of the country's first post-independence President for Life, Macias Nguema, received much less international attention. 4 This was due to two factors: a) the closed nature of the ruling government and b) Equatorial Guinea's miniature size. In the 1970's, Equatorial Guinea had only some 300,000 inhabitants.

Between 1968 and 1979, the repressive, brutal rule of Macias Nguema managed to completely destroy the economy, leaving the country's inhabitants demoralized.5 The excellent technical and social infrastructure, once the reason why much of colonial Africa saw Equatorial Guinea as their favourite recreation spot, lay in shambles soon after Nguema's takeover. Cocoa production - the comerstone of the country's economy declined from a preindependence peak of 38,000 tons, to less than 10,000 tons within only

3 Without much doubt Equatorial Guinea is a "white spot" even in the maps of some otherwise wellinformed African experts. The country has received little outside attention, resulting in almost no information about it: yet providing us with two additional reasons to analyze this particular country. However, how much our results can be taken as general evidence for the entire continent is a question this paper will attempt to address.

4 The following list provides an introductory overview of literature on the country's recent development: $R$. Pelissier, Equatorial Guinea: Autopsy of a Miracle, Africa Report, Vol. XXV, No. 3, 1980, pp. 10-14; IIK. Sundiata, The Structure of Terror in a Small State: Equatorial Guinea, in: R. Cohen (ed.), African Islands and Enclaves, Beverly Hills, London, New Delhi: Sage, 1983, pp. 81-100; S. Decalo, African Personal Dictatorships, The Joumal of Modem African Studies, Vol XXIII, No. 2, 1985, pp. 209-237; M. Liniger-Goumaz, Connaître la Guinée Equatoriale, Paris: Editions des Peuples Noirs, 1986; C. Jakobeit, Äquatorialguinea: Schwierige Rehabilitation, Afrika Spectrum, Vol. XXII, No. 2, 1987, pp. 145-156.

5 Estimates put the dictatorship's victims of up to 50,000 people, mainly from the technical and political intelligentsia. About one third of the inhabitants fled the country. See S. Baynham, Politics and Power in Equatorial Guinea, Africa Insight, Vol. XVI, No. 1, 1986, pp. 28-32. 
a few years. Spanish estate owners and Nigerian migrant laborers, two groups who had guaranteed this impressive productivity in cocoa, fled the country throughout in the 1970s.

In August 1979, a military coup led by Obiang Nguema, a nephew of Macias from the same predominant ethnic group, put an end to the chaotic rule of "undisputedly one of the twentieth century's most brutal dictators". 6 The first priority of the new govemment was to revive the country's economy. However, the development was, and is still hampered by a number of constraints. First, there exists an acute shortage of trained manpower on all levels. 7 Second, the destruction of the social infrastructure and with it, productive capacity still hampers efforts of economic rehabilitation. Third, the country's currency was hopelessly overvalued, thereby underming economic activities. Fourth, the Spanish owners absent, an increase in cocoa production was difficult to achieve. Fifth, after the Macias nightmare, foreign investors had lost complete faith in the stable and secure environment in Equatorial Guinea which had existed under Spanish rule.

The new government took a number of bold measures to address these problems. In the monetary sector, Equatorial Guinea joined the CFA Franc zone in 1985, thereby devaluing her currency by more than 80 per cent. 8 The government asked bi- and multilateral donors to provide foreign experts and assistance to address the economic situation. 9 In the cocoa sector, the Obiang adminstration invited former plantation owners to resume cocoa production and negotiated a cocoa rehabilitation project with the World Bank.10 Despite these efforts, however, production has not increased significantly in the 1980s. 11

In order to restore the faith of foreign investors in the new govemment policies, a legal scheme to protect human rights, property rights and foreign investments 12 was set up. The core of this effort was the next Constitution of 1982.13 The right to private property was

6 Ibidem, p. 30.

7 See C. Legum, Equatorial Guinea: Playing the French Card, Africa Contemporary Record 1984-85, New York, London: Africana Publishing Company, p. B 140.

8 See Liniger-Goumaz, op.cit., p. 150.

9 See The World Bank, Equatorial Guinea. An Introductory Economic Report, Washington, D.C.: The World Bank, 1984, p. II.

10 See The World Bank, Staff Appraisal Report Equatorial Guinea. Cocoa Rehabilitation Project, Washington, D.C.: The World Bank, 1985.

11 For a careful analysis of the problems in the cocoa sector see C. Jakobeit, Equatorial Guinea: Long Term Viability of Cocoa Production on Bioko, Hamburg, 1988 (unpublished report for the World Bank).

12 See the Foreign Investment Act of 1979: Decreto-Ley Num. 10/1979, de fecha 17 de noviembre, sobre Inversion de Capital Extran jero en Guinea Ecuatorial.

13 See Ley Fundamental de Guinea Ecuatorial Art. 74, 75, 76. The new constitution was approved by 95 per cent of the voters in a referendum on August 15, 1982. This legal document is reprinted in: 
guaranteed in Art. 74 and 75 and due the predominant agricultural economy, special protection was given to farmers. Art. 76 underlined that the state guarantees to farmers the traditional ownership of the land which they possess. The issue of property is still regulated in detail by the Spanish "Código Civil" and the "Ley y Reglamento Hipotecarios". This follows from Decreto-Ley Núm. 4/1980.14 This statute points out that in the field of criminal, civil, commercial, administrative, labor and military law the Spanish law will be substituted if there is no Guinean statute in existence.

However, the 1982 Constitution does not prohibit expropriation per se, as the experience from the Macias regime might have suggested. As in other countries, the right to private property is not unlimited. If there is a justified reason, for public utility of in the social interest 15 , fair compensation (indemnización correspondiente) is mandated for the then legally permitted expropriation. 16

\section{Cocoa Production in Equatorial Guinea}

The island Bioko17, the former Fernando Póo, provides excellent conditions for the production of cocoa. Whereas on the continent, climatic and soil conditions were less favourable, the high fertility from the island's volcanic soils, yielded up to 1 ton of dry cocoa per hectare on the colonial estates without any application of fertiliser.

A.P. Blaustein / G.H. Flanz, Constitutions of the Countries of the World, New York: Oceana Publications 1983.

14 Decreto-Ley Núm. 4/1980, de fecha 3 de abril, por el que se declaran de aplicación subsidiaria en la República de Guinea Ecuatorial las leyes penales, militares que regían hasta el 12 de octubre de 1968.

15 See Ley Fundamental de Guinea Ecuatorial Art. 75 (2), 74 (2).

16 If a new statute contradicts a fundamental property right, the constitution opens the possibility for scrutinizing its constitutionality. However, no law has yet been passed, which calls for the exercise of such a review procedure. The Supreme Court of Justice (Corte Suprema de Justicia) - the highest court in Guinea Equatorial - does not have any jurisdiction in the matters of constitutional quarantees. See Ley Fundamental de Guinea Ecuatorial Art. 40, 145. An administrative act that infringes the right of property is reviewable under the mechananism set up in the Administrative Procedure Act of 1980, Reguladora del Procedimiento Administrativo, Decreto-Ley número 28/1980, de fecha 11 de noviembre, Art. 84-97 (reprinted in: T. Obiang Nguema Mbasogo. Guinea Ecuatorial, País Joven, Malabo: Ediciones Guinea, 1985, pp. 247-280). In general, a citizen is allowed to apply for a review of an agency's action by the next administrative body in the hierachy, which has the power to confirm, to modify, or to revoke the original decision.

17 Bioko is situated off the Cameroonian Coast in The Gulf of Biafra and together with the continental part, Rio Muni, and the island Annobón, located south of Sao Tomé and Principe forms today's Equatorial Guinea. The country's capital, Malabo, is situated on Bioko. 
Cocoa production on Bioko began in the middle of the nineteenth century. With the increased demand in Europe, the Spanish colonial authorities pressured the major ethnic group on the island, the Bubis, to turn the more fertile soil over for cocoa production intended for Europe. However, the Bubis received either annual pensions, or school stipends for their sons in exchange for the land.18

Cocoa became the most important product on the island. As local Bubis refused to work on the European estates, the Spaniards imported migrant labor from Nigeria. Land was registered as the property of the individual European estate owner in the Registro de Propriedad in Malabo. Bringing relatively high prices from the Spanish mainland, cocoa rapidly became the country's economic backbone. At the end of the colonial period, some 45,000 hectares of land on Bioko were devoted to cocoa production.

Under Macias, most of the 8,000 Spaniards and the 35,000 Nigerians fled from the island. Cocoa production rapidly declined. Macias relied on forced labor from the mainland in order to keep up production. This, however, was insufficient to counterbalance the loss in expertise, and self-interest of those who had fled. By 1979, only some 17,500 hectares were still worked19, whereas the rest was abandoned. Productivity was now much more in line with the West African average of 400 kilograms per hectare.

The new post-Macias government put cocoa rehabilitation in the center of its economic recovery strategy. If the abandoned land were put into production again, the revenue in foreign exchange and taxes from increased cocoa exports could potentially finance the economic upswing. However, these initial steps taken by the govemment - the Foreign Investment Act and new Constitution guaranteeing property rights - led to a paradox: the legal framework was there, to use the land as the economic motor, but most former owners were unwilling to take repossession of it. What could the government do to solve this dilemma?

\section{Efforts to Overcome the Abandoned-Land Obstacle to Rehabilitation}

The first approach to overcome the problem of the abandoned land (Bienes Abandonados) 20 was used twice: shortly after the coup d'état in 1979 and at the beginning of 1984 .

18 See M. Liniger-Goumaz, La Guinée Equatoriale. Un pays méconnu, Paris: L'Harmattan, 1980, p. 93.

19 See the estimates in The World Bank, Staff Appraisal Report ..., op.cit., p. 10.

20 The legal tern "abandoned land" has been defined as land that is registered to a foreigner but that is not in an orderly status of cultivation. See for example Decreto-Ley Núm. 8/1984 Art. 2 
Under Decreto 51/1979 21 all foreign owners of farm land, who are registered in the Registro de Propiedad 22 and who abandoned their property, were obliged to recultivate their farms. They were also obliged to come up with the investment capital for cultivation and modemisation of their farms, as well as for any efforts at farm conservation that had been undertaken by the government during their absence. 23 The statute establishes a 60 day time period for fulfilling these obligations. 24 The Decreto states that in case the owners do not fulfill their obligations, their property can be nationalized and transferred to the Guinean state. The government then has the authority to reallocate the land to people who are able and willing to work it.25

This approach used by the Guinean government has precedence in the Spanish legal system. In Spain, it is called an expropriation for not fulfilling a specific social function of the property (expropriación por incumplimiento de la función social de la propriedad). 26 Interestingly enough, this procedure has also been used in Spain to expropriate uncultivated land in Andalusia. 27

In practice, however, the legal power to expropriate land from foreign owners wasn't used by the government. Instead, credits amounting to approximately 2000 million Bipkwele 28 were provided by Guinean banks as economic incentives to coax the former farmers back to Equatorial Guinea. However, this approach did not increase production. The number of people who actually reoccupied their land, as it was under the conditions of Decreto $51 / 1979$, was relatively low. New problems also came into existence: Some landowners

21 The official title of this legal document is: Decreto Núrn. 51/1979, de fecha 23 de octubre, por el que se concede un plazo de 60 dias a los propietarios extranjeros de empresas agrícolas de cacao, café, palmeral y otros, cuya titularidad esté debidamente acreditada por medio de su inscripción en el Registro da Propiedad de la República de Guinea Ecuatorial, a fin de que vengan a poner en explotacíon las fincas de su propriedad que en su día abandonaron.

22 At present, there are two registration offices in Guinea: one in Bata and one in Malabo. The office in Bata cannot employ a lawyer as registrar because of a lack of qualified people in Guinea. Furthermore, the offices have many organizational problems. However there is no information available as to whether these shortcomings are serious obstacles for an orderly registration process.

23 Decreto Núrn. 51/1979 Art. 1.

24 On January 4 th, 1980 the time period was extended to another 30 days.

25 Decreto 51/1979 Art. 2.

26 See, for example, F.G. Enterria/T R. Fernandez, Curso de Derecho Administrativo, Second Ed., Madrid, 1986, pp. 299-301.

27 See Boletin Oficial del Estado, 23 Noviembre 1978 (Núm. 281), Ley 16 noviembre 1979, Núm. 34/79 (Jefatura del Estado). Agricultura. Fincas Manifiestamente Mejorables; Boletin Oficial del Estado, 11 y 12 abril 1980 (Núms. 88 y 89), Orden 25 Marzo 1980, Agricultura. Criterios Objetivos para Determinación de las Fincas Manifiestamente Mejorables; and G.F. Farreres, Anotaciones a la Ley sobre Fincas Manifiestamente Mejorables (Ley 34/1979, 17 noviembre) in: Revista de Derecho Adminstrativo 1980, pp. 223-53.

28 See the Preamble of the Decreto-Ley Núm. 8/1984. 
who fulfilled these conditions didn't cultivate their farms, and again left the country. Many either didn't pay taxes or didn't pay back credits extended to them29, thereby aggravating the banking crisis as well.

Before the govemment changed its policy towards actually using its expropriation powers, it reconfirmed its offer on February 1984 for foreign owners to return to Equatorial Guinea to recultivate their farms. The Decreto Núm. 22/198430 "invited" all foreign owners of rural or urban land to reoccupy their property. In addition, the following demands 31 were made (these included those people who fulfilled the 1979 obligations as well 32 : a) all outstanding taxes and fines for not paying taxes were to be paid, b) all credits received from Guinean commercial banks were to be paid, c) all costs incurred to maintain the farms were to be paid (The amount was to be fixed on a case-by-case basis by Ministry of Finance (Ministerio de Finanzas)), d) in addition all investments undertaken for the purpose of exploiting the land were to be declared, and e) the conditions of the Foreign Investment Act were to be fulfilled. As in Decreto Núm. 51/1979 a time period of 60 days was established. If the previous owner couldn't fulfil these conditions, his property was liable to be confiscated. 33

Obviously, the government didn't believe that this attempt would be successful. In May 1984, therefore, Decreto-Ley Núm. 8/198434 expropriated all abandoned land owned by foreigners and transfered it to the Guinean state.35 Furthermore, all legal acts conceming the property of land during the Macias time were declared void.36

Finally, the state authorized itself to reprivatize the land.37 Decreto-Ley Núm. 8/1984 states 38 that land can be reprivatized if an adjudication by the president has been issued and the buyer has fulfilled his contractual obligations. The basic steps for receiving a

29 See, for example, the reasoning of Decreto Núm. 22/1984.

30 The full titel of this docurnent is: Decreto Núm. 22/1984, de fecha 20 de febrero, por el que se concede un plazo de 60 días a los extranjeros propietarios de fincas rústicas y urbanas en Guinea Ecuatorial, para recuperar sus propiedades y ponerlas en explotación.

31 Decreto Núm 22/1984 Art. 1.

32 Decreto Núm 22/1984 Art. 3.

33 Decreto Núm 22/1984 Art. 1.

34 The full titel is: Decreto-Ley Núm. 8/1984, de fecha 3 de Mayo, porel que se transfiere al Estado, la Propiedad de las fincas rústicas y urbanas abandonadas por los extranjeros en la República de Guinea Ecuatorial.

35 Decreto-Ley Núm. 8/1984 Art. 3.

36 See Decreto-Ley Núm. 8/1984 Art. 6.

37 Decreto-Ley Núm. 8/1984 Art. 4.

38 Art. 4. 
presidential approval are outlined in more detail in the regulations ${ }^{39}$ of the statute: First, the buyer must formally apply to purchase a specific abandoned farm in Equatorial Guinea. The prerequisites purchasing more than 50 hectares are a) providing a document certifying the economic capability to cultivate the land $40, b$ ) employing a sufficient number of workers to run the farm properly 41 , c) developing a cultivation plan 42 , and d) providing a certification of the Registro del Propiedad outlining the location and the nature of property.43 Additionally, foreigners must fulfil, the obligations established by the Foreign Investment Act. 44 Next the price will be fixed and the approval issued by the Presidencia and the responsible ministries. 45 When the fixed price has been paid and the new owner is registered in the Registro de Propiedad46 and the Registro Fiscal, all steps have been fulfilled.

The Community of Spanish People Interested in Africa (CEIA), to which the former Spanish landowners from Guinea belong, critisized this statute as unconstitutional.47 Indeed, the statute does not contain any provision for fair compensation, even though this is a prerequisite for an orderly expropriation of land under the 1982 constitution, as well as under intemational law.48 However, the CEIA has not petitioned Equatorial Guinean authorities for recompensation but rather, the Spanish govemment. It argues that the

39 Decreto Núm. 154/1984, de fecha 8 de Agosto, por el que se aprueba el Reglamento de aplicación del Decreto-Ley Núm. 8(1984, de fecha 3 de Mayo, por el que se transfiere al Estado la propiedad de las fincas rústicas y urbanas abandonadas pro los extranjeros en la República de Guinea Equatorial. This document is reprinted in: República de Guinea Ecuatorial, Boletin Oficial del Estado, 14 de Agosto de 1984, Malabo, pp. 4-7.

40 Decreto Núm. 154/1984 Art. 14 (2).

41 Decreto Núm. 154/1984 Art. 14 (4).

42 Decreto Núm. 154/1984 Art. 14 (5).

43 Decreto Núm. 154/1984 Art. 14 (3).

44 Decreto Núm. 154/1984 Art. 12.

45 Decreto Núm. 154/1984 Art. 16-18.

46 For this stage of the procedure the Spanish Código Civil and the Ley y Reglamento Hipotecarios applies.

47 The position of the former Spanish land owners is summarized in the following article of the Spanish weekly "Nacional": Mientras los antiguos colonos siguen pidiendo una indemnizacion: El presidente Obiang y sus ministros se han quedado con propiedades de los espanoles, Nacional, August 9th, 1987 pp. 8-9.

48 In the literature about intemational law, it is generally recognized that a legal expropriation requires the payment of fair compensation. See, with further references, R. Dolzer, Expropriation and Nationalization, in: Encyclopedia of Public Intemational Law, Vol. 8, Amsterdam, New York, Oxford: North Holland, 1985, pp. 214-221; W. Birke, Die Konfiskation ausländischen Privatvermögens im Hoheitsbereich des konfizierenden Staates nach Friedensvölkerrecht, Hamburg: Hansischer Gildenverlag, 1980, pp. 145-156; F. Francioni, Compensation for Nationalisation of Foreign Property: The Borderland between Law and Equity, Intemational and Comparative Law Quarterly, Vol. 24, 1985, pp. 255-266: O. Schachter, Compensation for Expropriation, The American Joumal of International Law, Vol. 78, 1984, pp. 121-130. 
recolonisation of Equatorial Guinea was not done in a manner that sufficiently recognizes the interests of Spanish property. 49 Therefore, Spain must be made responsible for 9000 mill. peseta that Spanish citizens lost after the independence of Equatorial Guinea in 1968.50 After having sued before different tribunals, the case has now reached the highest Spanish court - the Tribunal Constitucional.

\section{The Reprivatisation Procedure in Practice}

One of the basic practical obstacles to all reprivatization efforts has been the amount of investment needed to both purchase and modernize land which has remained unused for several years. In order to facilitate this undertaking the government set up a financing scheme. Under this procedure - used until the end of 1987 - land was allocated to an individual based on a five year contract with the government 51 ; obliging the buyer to pay ten per cent of the price immediately, with the rest in five equal instalments. The most important condition of this contract was the cultivation of the property. 52

Until the end of 1987, this financing scheme was only used for approximately half of the land abandoned and the individuals concerned are still in the process of establishing their ownership. Very few have reached the final stage of the five year process; that is, in possession of a valid land title. In general, most are either not able, or not willing, to pay the amount fixed in the contract.53 Under this procedure, one could only become the owner of a property if all the terms of the contract had been fulfilled. Otherwise the land is still the property of the state.

In the early 1980s, the announcement of the World Bank Cocoa Rehabilitation Project produced an interesting externality. When it became known that credit eligibility within the

49 Nacional, August 9th, 1987, p. 8.

50 Nacional, August 9th, 1987, p. 9.

51 The transfer of land between the owner and the buyer is basically a three step process. A contract between the parties (titulo) and the handing over of the possession to the buyer (modo) are basic prerequisites for obtaining ownership under the Spanish legal scheme. Furthermore, Art. 1280, 1279 Código Civil obliges the parties to obtain a notarized certificate of the contract (Escritura Pública). The Escritura Pública is a prerequisite for registering the property in the public property register (Registro de la Propriedad) as the last step of the transferring procedure. The registration covers the location, the borders, the surface, and the nature of the land concemed, as it is written in the contract. For a summary of this procedure see, for example, W. Löber, Grundeigentum in Spanien, Frankfurt: Edition für Intemationale Wirtschaft, 1984.

52 Interview with administrators in the Ministry of Agriculture, September 1987, Malabo.

53 Interview with administrators in the Ministry of Agriculture, September 1987, Malabo. 
project would depend upon land ownership, the reprivatization procedure took shape rapidly. 54

It is worth mentioning that the president, his family, his friends, members of the cabinet, and the bureaucracy - i.e. the administrative class of the country55 - seem to be the winners in the reprivatization exercise. At present, both the president and his brother each own some 1,000 hectares of excellent cocoa land. Most of the land is worked in small plots by parcelistas (tenants), who are provided with the necessary materials and some cash advances during the season and who, in turn, have to deliver all the cocoa to the estate owners. Today's main problems refer to the increasing indebtedness of many parcelistas; they are particularly vulnerable and can easily be cheated by the estate owners. This can create a system of landless poor laborers who are not particularly interested in expanding or intensifying cocoa production; since the possibility to achieve an independent status under the current legislation are almost nil.

Apart from the possibly unjust redistribution of the nationalized land, there are basically two shortcomings in the procedure. First, the required investments for starting cocoa cultivation were so high that profits were often too low to pay important portions of the outstanding rates. Second, the risk of not being able to fulfil the terms of the contract thereby losing all investment as well as the possibility to gain ownership of the land - was extremely high. If the season is poor and the international market prices are low, all invested capital can easily be lost. Most of those who signed the contract have not paid all the rates to which they were obliged; thereby have failed to meet the requirements of the law.56

In order to rescue the reprivatization efforts made so far, a new ten per cent procedure was proposed and promulgated at the end of 1987.57 The statute basically states that it is now possible to become the owner of abandoned land, if ten per cent of the land price has been paid to the government. 58 In order to prevent real estate speculation, the buyer is obliged to

54 The World Bank Rehabilitation Project became operational at the beginning of the 1986 season. See the World Bank, Staff Appraisal Report ..., op.cit.

55 For the discussion of the emergence of the phenomenon of an administrative class in developing societies, see $\mathrm{H}$. Elsenhans, Abhängiger Kapitalismus oder bürokratische Entwicklungsgesellschaft. Versuch über den Staat in der Dritten Welt, Frankfur/New York, 1981. In the African context, see $R$. Tetzlaff, Gibt es in Afrika eine Staatsklasse?, in: E.-M. Bruchhaus (ed.), Afrikanische Eliten zwanzig Jahre nach Erlangung der Unabhängigkeit, Hamburg, 1983.

56 Interview with administrators in the Ministry of Agriculture, September 1987, Malabo.

57 The bill called Decreto-Ley, por el que se garantiza la propiedad de fincas rústicas a los adjudicatarios. During the authors' stays in Malabo the correct quotation of the new statute was not available.

58 Art. 1. 
both present and realize a cultivation plan for a time period of five years ${ }^{59}$, and is not permitted to resell the land to a third person.60 If an individual cannot fulfil these obligations, the land must be returned to the state. The government will then redistribute it, in part to villages. 61

The future will show whether this procedure will be successful - whether land can be owned by those who work it, as well as those who are politically influential. A few general observations, however, cast some doubt on an optimistic scenario. First, it is commonly known that for almost every government permit or approval, an extra payment to the state functionary in charge - in other words, a bribe62 - has to be made. From this alone, the costs might be too high, even if the price of land is assessed at only a tenth of its value. Second, the government will still review whether the five year plan has been fulfilled. The review criteria are in the process of being established. The risk of losing the invested capital still remains, although the financial burden has been somewhat minimized. Third, the prohibition of selling the land to a third party will make it ifficult to get credit from the one remaining commercial bank. If a farmer cannot repay his loan, most likely the bank would have no right to auction off the property - assuming that it could find someone interested in buying it. From the banker's point of view, the new ten per cent procedure is no improvement, since land will be often unacceptable as collateral for a loan.

\section{Final Evaluation}

The situation in Equatorial Guinea today highlights a number of shortcomings in the attempt to reactivate cocoa production on abandoned farm land. The former Spanish owners have not taken repossession of their lands; and their claims for recompensation are still not settled. However, as they seek recompensation only from the Spanish authorities, they implicitly acknowledge the Equatorial Guinean government's inability to pay for their former properties.

From a purely legal point of view the reprivatization procedure tries to make it as attractive as possible to take possession of abandoned land. However, the economic constraints are such that investing money in cocoa rehabilitation is a high risk endeavour with questionable chances of success. Distributive considerations reveal another shortcoming of the procedure so far. Abandoned land - in particular the most fertile - has largely been allocated to the

59 Art. 2.

60 Art. 6.

61 This first step to a "land reform" is mentioned in Art. 4.

62 For a more general analysis of comuption in third world countries see $R$. Klitgaard, Controlling Corruption, Berkeley, Los Angeles, London: University of California Press, 1988. 
administrative class, thereby encouraging the emergence of a parcelista system of production. This system provides only limited economic incentives to increase production, as those who work the land do not own it.

The principal political conclusion that we draw from our evaluation stresses the need for a wider-ranging land reform which would provide the necessary incentive to increase production. If neither the former Spanish estate owners, nor the new owners from the administrative class are willing to work on the land, it must be reallocated to those who do. Being able to use their own land as collateral for loans, these owners from more modest circumstances could possibly guarantee that cocoa can be the engine for economic growth in Equatorial Guinea, provided that world market prices and intemal support are such that the necesseary efforts will be rewarded.

\section{Conclusion}

The history of Equatorial Guinea illustrates that communal ownership of land was already replaced by individual land rights in colonial days, providing yet another example against the widespread misconception that communal land ownership predominates in Africa. The natural conditions for the production of cocoa are such that the crop can potentially be the motor for economic development on the island of Bioko. However, neither the individual land title, nor the constitutional guarantee of property rights, nor the registration and orderly process of being able to see one's land, are sufficient conditions to enhance economic development.

The newly emerging system after 1979 once again confirms the Spanish legacy. As in the pre-independence period, land is once more distributed to the powerful, whereas those who work it are basically left out. We see a parallel to the conditions in much of Latin America, where a land reform is the precondition for sustained agricultural development. In sum, the land issue in Equatorial Guinea has much in common with the situation in other former Spanish colonies in America and is thus more of a special case for Africa. 


\title{
A Note on Privatization of State Enterprises in Ghana
}

\author{
By Joseph R.A. Ayee
}

Ghana's Provisional National Defence Council (PNDC) has resorted to the policy of privatization as an antidote to the dismal performance of state enterprises in the country. The article examines the privatization policy of the PNDC and argues that state intervention in the economy is justified and necessary. In the writer's view, privatization does not necessarily improve the viability of state enterprises, since it is fraught with numerous problems.

\section{The State Law and Urban Poverty in Tansania}

\section{By Joe L.P. Lugalla}

This paper is about the state, law and urban poverty in Tanzania. The paper examines how the state in Tanzania has been trying to solve the problem of urban poverty. The main argument is that the state's conception of urban poverty is not realistic. The urban poor are seen as responsible for their poverty. This is confirmed by the kind of coercive policies, legislation and other measures which have been instituted by the state in order to solve the problem. The paper argues that due to lack of a critical analysis of the causes of poverty, the state has been implementing policies which have exacerbated the problem, because they have treated the symptoms rather than the essential relations. The paper concludes by arguing that law, like other policies, has to assist the process of social and economic development. Rather than criminalizing the poor, in developing socialist countries like Tanzania law has to assist them.

\section{Property Rights and Agricultural Development. \\ The Land Issue in Equatorial Guinea}

\section{By Bernd Holznagel, Cord Jakobeit}

This paper illustrates the argument that land rights in Africa evolve in response to changing political, social and economic conditions. The case of Equatorial Guinea has more in common with the situation in other former Spanish colonies in America than with the typical African situation. A system of individual titles to the land, orderly registration and 
established procedures for sale of land and its use as a collateral for a loan had already emerged in the colonial days.

Today, conditions for the production of cocoa are such that it can possibly be a motor for the country's economic development.

The paper discusses the attempts after the coup d'état of 1979 to redistribute the land. Again, the parallels to the situation in Latin America are striking. Land is increasingly organized into large estates owned by the administrative class, whereas those who work it are left basically landless. The author argue that only a land reform -- among other necessary conditions -- that addresses this imbalance can provide the incentive to put cocoa once more in its place as an engine of growth.

The Coordination between Silent Partner and Owner:

A Consultative Committee for the Development of of the Senegal River

By Hans-Werner Wabnitz

The author presents a revised version of a lecture held at the international seminar on the role of law regarding to financial development and investments in Africa, 25.-27.5.1988 at Bangui University. The lectures are condensed in a volume edited by the University of Bangui, summer 1988.

\section{ECOWAS - Economic Community of West African States}

By S.B. Ajulo

ECOWAS has become an exemplarly economic community as for the first time one has succeeded in creating a community of African States with different colonial background. Problems will arise still, but if the community stands the test this will be a chance to the future and a contribution by West Africa to international commercial law in general and international law in particular. Should this trial for cooperation fail, another arrangement would be made. As the social structure of West African States is intermingled the current economic dependency on each other will grow thus making the political borders a potential menace to peace. 